\title{
Carbon transfer, partitioning and residence time in the plant-soil system: a comparison of two ${ }^{13} \mathrm{CO}_{2}$ labelling techniques
}

\author{
M. S. Studer ${ }^{1,2}$, R. T. W. Siegwolf ${ }^{2}$, and S. Abiven ${ }^{1}$ \\ ${ }^{1}$ Department of Geography, University of Zurich, Winterthurerstr. 190, 8057 Zürich, Switzerland \\ ${ }^{2}$ Laboratory of Atmospheric Chemistry, Paul Scherrer Institute, 5232 Villigen PSI, Switzerland
}

Correspondence to: S. Abiven (samuel.abiven@geo.uzh.ch)

Received: 26 September 2013 - Published in Biogeosciences Discuss.: 22 October 2013

Revised: 14 January 2014 - Accepted: 14 February 2014 - Published: 27 March 2014

\begin{abstract}
Various ${ }^{13} \mathrm{CO}_{2}$ labelling approaches exist to trace carbon (C) dynamics in plant-soil systems. However, it is not clear if the different approaches yield the same results. Moreover, there is no consistent way of data analysis to date. In this study we compare with the same experimental setup the two main techniques: pulse and continuous labelling. We evaluate how these techniques perform to estimate the $\mathrm{C}$ transfer time, the $\mathrm{C}$ partitioning along time and the $\mathrm{C}$ residence time in different plant-soil compartments.

We used identical plant-soil systems (Populus deltoides $\times$ nigra, Cambisol soil) to compare the pulse labelling approach (exposure to 99 atom $\%{ }^{13} \mathrm{CO}_{2}$ for three hours, traced for eight days) with a continuous labelling (exposure to 10 atom $\%{ }^{13} \mathrm{CO}_{2}$, traced for 14 days). The experiments were conducted in climate chambers under controlled environmental conditions. Before label addition and at four successive sampling dates, the plant-soil systems were destructively harvested, separated into leaves, petioles, stems, cuttings, roots and soil and soil microbial biomass was extracted. The soil $\mathrm{CO}_{2}$ efflux was sampled throughout the experiment. To model the $\mathrm{C}$ dynamics we used an exponential function to describe the ${ }^{13} \mathrm{C}$ signal decline after pulse labelling. For the evaluation of the ${ }^{13} \mathrm{C}$ distribution during the continuous labelling we applied a logistic function.

Pulse labelling is best suited to assess the minimum $\mathrm{C}$ transfer time from the leaves to other compartments, while continuous labelling can be used to estimate the mean transfer time through a compartment, including short-term storage pools. The $\mathrm{C}$ partitioning between the plant-soil compartments obtained was similar for both techniques, but the time of sampling had a large effect: shortly after labelling the allocation into leaves was overestimated and the soil ${ }^{13} \mathrm{CO}_{2}$
\end{abstract}

efflux underestimated. The results of belowground $\mathrm{C}$ partitioning were consistent for the two techniques only after eight days of labelling, when the ${ }^{13} \mathrm{C}$ import and export was at equilibrium. The $\mathrm{C}$ mean residence times estimated by the rate constant of the exponential and logistic function were not valid here (non-steady state). However, the duration of the accumulation phase (continuous labelling) could be used to estimate the $\mathrm{C}$ residence time.

Pulse and continuous labelling techniques are both well suited to assess $\mathrm{C}$ cycling. With pulse labelling, the dynamics of fresh assimilates can be traced, whereas the continuous labelling gives a more integrated result of $\mathrm{C}$ cycling, due to the homogeneous labelling of $\mathrm{C}$ pools and fluxes. The logistic model applied here, has the potential to assess different parameters of $\mathrm{C}$ cycling independent on the sampling date and with no disputable assumptions.

\section{Introduction}

Carbon (C) cycling within terrestrial ecosystems has been extensively studied in the last decades, still many processes and plant-soil-atmosphere $\mathrm{C}$ fluxes are not well understood. How single plants or whole ecosystems will respond to changes in climate (temperature, water availability and atmospheric $\mathrm{CO}_{2}$ concentration) is still a matter of intense research. Of special interest is the speed of $\mathrm{C}$ cycling, the $\mathrm{C}$ allocation patterns and the $\mathrm{C}$ residence time within different compartments of the plant-soil system, in order to better understand the interactions between different processes and predict the changes in terrestrial $\mathrm{C}$ fluxes induced by climate change. 
Stable isotope tracing is a powerful tool to study the $\mathrm{C}$ fluxes and pools within the plants and the soil with minor disturbance (Brüggemann et al., 2011; Dawson et al., 2002; Werner et al., 2012). The use of natural labelling approaches (based on isotopic fractionation occurring during biochemical reactions in plant and soil) is valuable in many cases, but is inappropriate if more than two sources are involved or if the difference in the isotopic composition of the sources is too small (Bowling et al., 2008; Werth and Kuzyakov, 2010). Artificial labelling techniques (using stable or radioactive isotopes) can overcome these difficulties (Amelung et al., 2008; Epron et al., 2012; Glaser, 2005).

In the last decades, various labelling approaches have been used. These approaches differ in the duration of label exposure, the applied label strength and the sampling intervals. Two main techniques can be distinguished to label organic matter by exposure of the plant to labelled $\mathrm{CO}_{2}$ : pulse and continuous labelling (field of applications reviewed in Meharg, 1994; Kuzyakov and Domanski, 2000). In a pulse labelling (PL) experiment, highly ${ }^{13} \mathrm{C}$ enriched $\mathrm{CO}_{2}$ (usually 99 atom $\left.\%{ }^{13} \mathrm{CO}_{2}\right)$ is added in a pulse, i.e. over a short period of time (a few hours) and the label is traced in the plantsoil system in the following days (Epron et al., 2012; Leake et al., 2006). In continuous labelling (CL) experiments, the plant is continuously exposed to less strongly labelled $\mathrm{CO}_{2}$ (generally $<10$ atom $\%{ }^{13} \mathrm{CO}_{2}$ ) or ${ }^{13} \mathrm{C}$ - depleted $\mathrm{CO}_{2}$ over the whole experimental period and samples are taken during and/or at the end of the labelling (e.g. in Esperschütz et al., 2009; Yevdokimov et al., 2006). With continuous labelling, $\mathrm{C}$ dynamics can be studied over larger time periods, as for example in Free Air $\mathrm{CO}_{2}$ Enrichment (FACE) experiments, where whole ecosystem areas are exposed to elevated $\mathrm{CO}_{2}\left({ }^{13} \mathrm{C}\right.$ - depleted) for several years (e.g. in Grams et al., 2010; Keel et al., 2006). However, the continuous labelling technique has also been applied at the same time scales as the pulse labelling technique (days-weeks), but it is not clear if these approaches yield the same results regarding $\mathrm{C}$ cycling within plant-soil systems and how we can interpret them. While there are generally accepted approaches to analyse the ${ }^{13} \mathrm{C}$ dynamics in plants after pulse labelling (exponential model), no consistent approach exists for the continuous labelling technique.

To make best use of the two ${ }^{13} \mathrm{CO}_{2}$ labelling techniques and their results, a proper evaluation of the techniques is essential. A comparison based on literature is difficult, since they have been applied to numerous plant species and soil types and under a variety of environmental conditions. Studies based on identical plant-soil systems grown under controlled environmental conditions are needed in order to elucidate the potential of these labelling techniques to assess $\mathrm{C}$ dynamics and to evaluate how one can compare them. To our knowledge, only one study has made such a direct comparison so far, in which the focus lay on the effect of labelling duration on belowground $\mathrm{C}$ partitioning (Warembourg and Estelrich, 2000).
In this study we compare the results for above- and belowground plant-soil compartments, obtained by pulse and (short-term) continuous labelling and discuss their potential to estimate the $\mathrm{C}$ transfer time, $\mathrm{C}$ partitioning and $\mathrm{C}$ residence time. We suggest a new approach to assess the $\mathrm{C}$ dynamics based on the ${ }^{13} \mathrm{C}$ dynamics during continuous labelling, test if the results regarding $\mathrm{C}$ cycling are comparable for both techniques and if the time point of sampling matters.

\section{Material and methods}

\subsection{Plants and soil}

Poplar trees (Populus deltoides $\times$ nigra, Dorskamp clone) were grown in a cambisol soil, sampled from the upper $15 \mathrm{~cm}$ in a beech forest $\left(8^{\circ} 33^{\prime} \mathrm{E}, 47^{\circ} 23^{\prime} \mathrm{N}, 500 \mathrm{~m}\right.$ elevation $)$. The soil had a clay loam texture (20\% sand, $45 \%$ silt, $35 \%$ clay), with a $\mathrm{pH}$ of 4.8 and an organic $\mathrm{C}$ and $\mathrm{N}$ content of 2.2 and $0.2 \%$, respectively. The soil was sieved by hand through a square sieve $(2.5 \times 3.5 \mathrm{~cm})$ leaving the soil structure largely intact, while large pieces of organic material and coarse gravel were removed. The plant pots were filled with $7.5 \mathrm{dm}^{3}$ moist soil (average dry weight of $2642 \pm 402 \mathrm{~g}$ ).

The poplar trees, 15 per experiment, were grown indoors under artificial light by sprouting from stem cuttings for five weeks and were then transferred into the labelling chambers (described below), where they were left for one week to acclimatize prior to labelling. One day before labelling the dry weight of newly produced biomass (plant biomass without the cutting) was $4.0 \pm 1.2 \mathrm{~g}$ and the total leaf area $692 \pm 113 \mathrm{~cm}^{2}$ per plant. During the PL and CL experiment the plant biomass increased by 28 and $65 \%$ and the leaf area by 42 and $111 \%$, respectively.

\subsection{Labelling chamber and procedure}

\subsubsection{The MICE facility}

The experiments were conducted in the "Multi-Isotope labelling in a Controlled Environment" (MICE) facility at the University of Zurich. The upper parts of the plant-soil system (shoots) are hermetically separated from the lower parts (roots, soil). The upper part of the chamber has a volume of $1.2 \mathrm{~m}^{3}$ (area $0.94 \mathrm{~m}^{2}, 1.24 \mathrm{~m}$ height) and is made of transparent polycarbonate plates. To facilitate sampling with minor disturbances to the labelling atmosphere, small sampling windows are installed in the front plate of the chamber. The lower part of the chamber consists of 15 individual plant pots.

The front plate of the chamber can be removed and the bottom plate has five open gaps with a width of $2 \mathrm{~cm}$, where the plants can be slid in. The gaps are closed with polycarbonate pieces and malleable sealant (Terostat IX, Henkel AG $\&$ Co.) wrapped around the cuttings, to prevent the diffusion of the labelled gas from the plants' atmosphere into the soil. The plant roots are in individual soil pots, which 
are also hermetically separated from the room atmosphere. The pots are aerated individually, with ambient air (flow rate $=0.8 \mathrm{~L} \mathrm{~min}^{-1}$ ), to prevent anaerobic conditions. Further, each pot has a separate in- and outlet for watering.

The environmental conditions in the chamber $\left(\mathrm{CO}_{2}\right.$ concentration, air humidity and light) are automatically regulated (valve system programmed with LabVIEW, National Instruments Switzerland Corp.). The ${ }^{12} \mathrm{CO}_{2}$ and $\mathrm{H}_{2} \mathrm{O}$ concentrations in the chamber atmosphere and of the pot in- and outlets are monitored online with infrared gas analysers (LI840A, LI-COR Inc.). In addition, gas samples can be taken manually from up to nine individual pots for further analysis of the soil ${ }^{13} \mathrm{CO}_{2}$ efflux.

\subsubsection{Labelling procedure}

To label the plants we added $\mathrm{CO}_{2}$ enriched in ${ }^{13} \mathrm{C}$ to the shoots (upper chamber system). In the pulse labelling (PL) experiment, the $\mathrm{CO}_{2}$ concentration in the chamber was reduced first, after the lights switched on, to $250 \mathrm{ppm}$ within $0.5 \mathrm{~h}$. Then 99 atom $\%{ }^{13} \mathrm{CO}_{2}$ (Cambridge Isotope Laboratories, Inc.) was injected up to a concentration of $1000 \mathrm{ppm} \mathrm{CO} \mathrm{CO}_{2}$ and kept on this concentration level $\left(\mathrm{CO}_{2}\right.$ saturation) for $2.5 \mathrm{~h}$. After flushing the chamber with ambient air, the plant shoots were exposed to $\mathrm{CO}_{2}$ with isotopic signatures close to ambient air $\left(\delta^{13} \mathrm{C}=-3 \%\right.$ ) from a $\mathrm{CO}_{2}$ gas cylinder till the end of the experiment ( 8 days). In the continuous labelling (CL) experiment, 10 atom $\%{ }^{13} \mathrm{CO}_{2}(\mathrm{Cam}-$ bridge Isotope Laboratories, Inc.) was added continuously to the upper chamber system (for 14 days).

Due to technical restrictions the light intensity within the labelling chambers was low $\left(79 \pm 25 \mu \mathrm{mol} \mathrm{m}^{-2} \mathrm{~s}^{-1}\right)$ and the temperature high $\left(31 \pm 3^{\circ} \mathrm{C}\right)$. Day-night cycles of twelve hours allowed for a positive $\mathrm{C}$ balance. To ensure optimal $\mathrm{C}$ assimilation at the given light availability, the $\mathrm{CO}_{2}$ concentration was held on a high level (495-540 ppm), the soil was kept moist (close to $100 \%$ field capacity) and the plants were grown in a humid environment (65-74\% relative air humidity) throughout both experiments.

\subsection{Sample collection}

\subsubsection{Destructive harvests}

The plant-soil systems were destructively harvested at five sampling dates with three replicates each. The first sampling was done one day before the labelling experiment started and represents the natural isotopic background signature (thereafter referred to as sampling date $t=0$ ). Subsequently, plantsoil systems were sampled 0.1 ( $2 \mathrm{~h}), 1,2$ and 8 days after the pulse labelling and after 1, 2, 8 and 14 days during the continuous labelling experiment. The sampled bulk materials were dried in the oven $\left(24 \mathrm{~h}\right.$ at $\left.60^{\circ} \mathrm{C}\right)$ for later $\delta^{13} \mathrm{C}$ analysis.

At each sampling date, the total leaf area was measured with a handheld area meter (CID-203 Laser leaf area me- ter, CID Inc.) and the plant-soil systems were separated into leaves, petioles, stems, cuttings, roots (washed with deionised water and carefully dabbed with tissue) and bulk soil (visible roots were removed with tweezers). The soil microbial biomass was extracted from fresh soil by chloroform fumigation extraction (CFE). The extraction was performed according to Murage and Voroney (2007), but we used $1 \mathrm{M} \mathrm{KCl}$ and did not remove excess salts. Subsamples of the CFE extracts were stored in a freezer for later elemental analysis. The remaining CFE extracts were freeze-dried for $\delta^{13} \mathrm{C}$ analysis.

\subsubsection{Soil respiration}

Soil $\mathrm{CO}_{2}$ efflux samples were collected one day before the beginning of the labelling, five times during the first day ( 2 , $4,6,8,21 \mathrm{~h}$ ) and after $1,2,3,4,5$ and 8 days in both experiments. During the CL, additional samples were collected after 11 and 14 days. The gas samples were taken from three pots corresponding to the last sampling date. To analyse the soil ${ }^{13} \mathrm{CO}_{2}$ efflux, each pot was connected to a closed loop. A pump circulated the air (flow rate of $0.8 \mathrm{~L} \mathrm{~min}^{-1}$ ) from the pot to a T-piece, equipped with a septum for manual gas sampling, through the gas analyser (LI-840A, LI-COR Inc.) and back to the same pot. At each sampling date, three gas samples per pot were taken for $\delta^{13} \mathrm{C}$ analyses. First, the air used to aerate the pots was sampled (atmospheric background). Then the pot was cut off from the aeration and linked to the loop. Two samples with a span of $100 \mathrm{ppm} \mathrm{CO}_{2}$ were taken in order to assure a high precision in the estimation of the isotopic signature of the soil respiration (Pataki, 2003). The soil respiration rate was assessed by the slope of the linear regression line of the increase in the $\mathrm{CO}_{2}$ concentration measured between the two sampling times.

The isotopic signature of the soil respiration was then estimated by the Keeling plot approach (Keeling, 1958; Pataki, 2003). The approach is based on a two end-member mixing model (assuming preservation of mass), where the two endmembers are the atmospheric background and the soil ${ }^{13} \mathrm{CO}_{2}$ efflux. The isotopic signature of the sampled $\mathrm{CO}_{2}$ (in the pot) shows a linear relationship to the inverse of its concentration. The intercept of the linear regression line yields the isotopic signature of one end-member (soil ${ }^{13} \mathrm{CO}_{2}$ efflux). In a recent publication, Brand and Coplen (2012) have demonstrated the nonlinearity of the $\delta$ notation and that $\delta$ values should consequently not be used to assess mass balances when the differences in the $\delta$ values are large (as it is usually the case in labelling experiments). Therefore, we used ${ }^{13} \mathrm{C}$ atom fraction, instead of the $\delta$ values, to calculate the signature of the soil respiration based on the Keeling plot approach. 


\subsection{Isotopic and elemental analysis}

\subsubsection{Procedure}

The dried plant and soil samples were milled to a fine powder with a steel ball mill and weighed into tin capsules. The elemental $\mathrm{C}$ content of the solid samples was analysed in an elemental analyser (CHN-900, Leco Corp). The elemental C analysis of the liquid CFE extracts was performed by a TOC500 analyser (Shimadzu Corp.).

The isotopic analyses were done by isotope ratio mass spectrometry (IRMS). To estimate the isotope ratios, the solid samples were combusted in an elemental analyser (EA 1110, Carlo Erba) and the resulting $\mathrm{CO}_{2}$ was transferred in a helium stream via a variable open-split interface (ConFlo II, Finnigan MAT) to the mass spectrometer (Delta S, Thermo Finnigan; Werner et al., 1999). The precision of the $\delta^{13} \mathrm{C}$ solids analyses was $\pm 0.12 \%$ (CL) and $\pm 0.09 \%$ (PL). The gaseous soil $\mathrm{CO}_{2}$ efflux samples were transferred in a helium stream directly from the gasbench (Gasbench II, Thermo Finnigan) to the mass spectrometer (Delta Plus XL, Thermo Finnigan). The precision of the gaseous $\delta^{13} \mathrm{C}$ analyses was $\pm 0.44 \%$ (CL) and $\pm 0.51 \%$ (PL). The precisions indicated here are the standard deviations of working standards (leaf biomass, commercially available $\mathrm{CO}_{2}$ ) measured frequently along with the experimental samples.

\subsubsection{Calculations}

The isotopic ratios measured were expressed in the delta $(\delta)$ notation relative to the international standard Vienna Pee Dee Belemnite (V-PDB, $\left.{ }^{13} \mathrm{C} /{ }^{12} \mathrm{C}=0.0111802\right)$. The significance of the ${ }^{13} \mathrm{C}$ enrichment was tested by $t$ tests (unpaired, two-sided, $\mathrm{R}$ statistics) at the individual sampling dates $(t=x)$, compared to the natural isotopic background measured before labelling $(t=0)$. The excess atom fraction $x^{\mathrm{E}}\left({ }^{13} \mathrm{C}\right) \mathrm{P} /$ reference within a plant-soil compartment, was calculated according to Coplen (2011) in order to assess mass balances (reference is $t=0$ ). The total mass of label recovered in excess $m^{\mathrm{E}}\left({ }^{13} \mathrm{C}\right.$ ) (in $\mathrm{mg}{ }^{13} \mathrm{C}$ ) within the plant tissues, the soil, the microbial biomass and the soil respiration was then calculated by multiplying the excess atom fraction with the $\mathrm{C}$ pool size or $\mathrm{C}$ flux present and taking into account the change in molar $\mathrm{C}$ weight due to the ${ }^{13} \mathrm{C}$ tracer addition (Eqs. 1-3), as suggested by Brand and Coplen (2012).

$$
\begin{aligned}
& m^{\mathrm{E}}\left({ }^{13} \mathrm{C}\right)_{\mathrm{PT}, \mathrm{S}}[\mathrm{mg}] \\
& =\frac{x^{\mathrm{E}}\left({ }^{13} \mathrm{C}\right)_{\mathrm{PT}, S} \cdot m(\mathrm{C})_{\mathrm{PT}, S} \cdot M\left({ }^{13} \mathrm{C}\right)}{x\left({ }^{12} \mathrm{C}\right)_{\mathrm{PT}, S} \cdot M\left({ }^{12} \mathrm{C}\right)+x\left({ }^{13} \mathrm{C}\right)_{\mathrm{PT}, S} \cdot M\left({ }^{13} \mathrm{C}\right)},
\end{aligned}
$$

where $m(\mathrm{C})_{\mathrm{PT}, S}$ is the mass (in $\mathrm{mg}$ ) of $\mathrm{C}$ present in a plant tissue (PT) or in the soil organic matter $(S), x\left({ }^{12} \mathrm{C}\right)_{\mathrm{PT}, S}$ and $x\left({ }^{13} \mathrm{C}\right)_{\mathrm{PT}, S}$ is its ${ }^{12} \mathrm{C}$ and ${ }^{13} \mathrm{C}$ atom fraction, respectively, and $M\left({ }^{12} \mathrm{C}\right)$ and $M\left({ }^{13} \mathrm{C}\right)$ the molar weight $\left(\mathrm{mg} \mathrm{mol}^{-1}\right)$ of ${ }^{12} \mathrm{C}$ and ${ }^{13} \mathrm{C}$.

$m^{\mathrm{E}}\left({ }^{13} \mathrm{C}\right)_{\mathrm{MB}}[\mathrm{mg}]$

$=\frac{x^{\mathrm{E}}\left({ }^{13} \mathrm{C}\right)_{\mathrm{MB}} \cdot m_{\mathrm{S}} \cdot c(\mathrm{C})_{\mathrm{MB}} \cdot M\left({ }^{13} \mathrm{C}\right)}{x\left({ }^{12} \mathrm{C}\right)_{\mathrm{MB}} \cdot M\left({ }^{12} \mathrm{C}\right)+x\left({ }^{13} \mathrm{C}\right)_{\mathrm{MB}} \cdot M\left({ }^{13} \mathrm{C}\right)}$,

where $m_{\mathrm{S}}$ is the mass of soil (in mg dry weight) and $c\left(\mathrm{C}_{\mathrm{MB}}\right)$ is the microbial biomass (MB) $\mathrm{C}$ concentration (fraction of total soil dry weight). The latter was assessed by elemental analysis of the fumigated vs. non-fumigated CFE extracts, applying a conversion factor of 0.45 , as suggested by Joergensen (1996).

$$
\begin{aligned}
& m^{\mathrm{E}}\left({ }^{13} \mathrm{C}\right)_{\mathrm{SR}}\left[\mathrm{mg} \mathrm{day}^{-1}\right] \\
& =\frac{x^{\mathrm{E}}\left({ }^{13} \mathrm{C}\right)_{\mathrm{SR}} \cdot F(\mathrm{C})_{\mathrm{SR}} \cdot M\left({ }^{13} \mathrm{C}\right)}{x\left({ }^{12} \mathrm{C}\right)_{\mathrm{SR}} \cdot M\left({ }^{12} \mathrm{C}\right)+x\left({ }^{13} \mathrm{C}\right)_{\mathrm{SR}} \cdot M\left({ }^{13} \mathrm{C}\right)},
\end{aligned}
$$

where $F(\mathrm{C})_{\mathrm{SR}}$ is the soil respiration (SR) rate (in $\mathrm{mg} \mathrm{C}$ day $^{-1}$ ) extrapolated to $24 \mathrm{~h}$.

The cumulative loss of ${ }^{13} \mathrm{C}$ by soil respiration (in $\mathrm{mg}$ ) was estimated by the integral of the curve fits, for the three measured pots separately. To fit the curve in the PL experiment, we used the model proposed by Warembourg and Estelrich (2000). The increase at the beginning was described by a logarithmic function and the decline of the signal after the label peak with an exponential function. In the CL experiment we used a logistic function to fit the curve, as described below.

\subsection{Tracing ${ }^{13} \mathrm{C}$ to assess $\mathrm{C}$ dynamics}

\subsubsection{Description of the ${ }^{13} \mathrm{C}$ distribution}

The dynamics of ${ }^{13} \mathrm{C}$ recovered after PL in the plant-soil compartments are characterised by three phases (Fig. 1a). An initial lag phase (no detectable signal), a phase dominated by the import of ${ }^{13} \mathrm{C}$ from other compartments, until a maximum label strength is reached (peak) and a phase of net ${ }^{13} \mathrm{C}$ export (exponential decay), controlled by ${ }^{13} \mathrm{C}$ transfer to other compartments and respiratory losses. Thus the import versus export of ${ }^{13} \mathrm{C}$ determines the shape of the signal peak (as discussed in Epron et al., 2012).

There is no consistent approach to describe the ${ }^{13} \mathrm{C}$ dynamics in the plant-soil system during CL (of pre-existing plants). Warembourg and Estelrich (2000) used a logarithmic function to describe the tracer dynamics in experiments with different labelling durations. However, when plants were exposed continuously to the label, they observed sigmoidalshaped curves. We tested the logistic and the logarithmic curve fit on our ${ }^{13} \mathrm{C}$ mass excess data. In all plant-soil compartments the logistic model yielded a better fit than the logarithmic model and it proved to be quite robust (Supplement). Therefore we applied a logistic function to describe the tracer dynamics within plant-soil compartments during CL experiments.

Logistic growth functions have their origin in ecology (population growth), but they have also been used to describe the accumulation of specific compounds and nutrients 
in plant tissues (e.g. in Bonvehi et al., 1997; Moustakas and Ntzanis, 2005; Iwahashi et al., 2012; Gutierrez-Gonzalez et al., 2013). As after pulse labelling, three phases can be distinguished (Fig. 1b), which represent the development towards homogeneously labelled $\mathrm{C}$ pools. The initial lag phase reflects the ${ }^{13} \mathrm{C}$ transfer time, i.e. the time needed for the ${ }^{13} \mathrm{C}$ to be transported from the chloroplast to the particular plantsoil compartment, analogous to the lag phase in the PL. A phase of exponential (net) ${ }^{13} \mathrm{C}$ accumulation follows thereafter, which slows down after the inflection point, due to increased labelling of the $\mathrm{C}$ export (respiratory losses, transfer to other compartments). In the final stage (stationary phase) the $\mathrm{C}$ import and export are homogeneously labelled, i.e. the ${ }^{13} \mathrm{C}$, which is introduced into the compartment, is in equilibrium with the ${ }^{13} \mathrm{C}$ exported. If the system is in a nonsteady state, the stationary phase would only be temporary. For example, during plant growth, the amount of ${ }^{13} \mathrm{C}$ would steadily increase after the steady state (second accumulation phase, Fig. 1b).

\subsection{2 $\mathrm{C}$ transfer time and $\mathrm{C}$ partitioning}

The speed of $\mathrm{C}$ transfer is usually assessed by the first significant ${ }^{13} \mathrm{C}$ signal detection ("lag time"), but the period to the maximum has also been used as indicator for the $\mathrm{C}$ transfer time in PL studies (Kuzyakov and Gavrichkova, 2010). We used the lag time to assess the minimum transfer time of fresh assimilates from the leaves to other plant-soil compartments. The mean transfer times of $\mathrm{C}$ within the plant-soil compartments were estimated by the time of the signal peak (PL) or the time of inflection (CL) minus the lag phase (which was negligible in this study with small tree seedlings). The mean $\mathrm{C}$ transfer time reflects the time needed until the majority of the labelled compounds are transferred into a plant or soil compartment and the export of the labelled compounds gains importance.

The $\mathrm{C}$ partitioning was assessed with both techniques by the relative ${ }^{13} \mathrm{C}$ distribution within the different plant-soil compartments at each sampling date. The fraction of ${ }^{13} \mathrm{C}$ within the leaf, petiole, stem, cutting, root and microbial biomass (in \%) was calculated as total amount of ${ }^{13} \mathrm{C}$ in the compartment, relative to the sum of ${ }^{13} \mathrm{C}$ in all compartments. The belowground $\mathrm{C}$ partitioning was estimated analogously, for roots, microbial biomass and cumulative respiratory $\mathrm{C}$ loss. The bulk soil was excluded due to the lack of significant signal detection. The effect of sampling date and labelling technique on the estimation of $\mathrm{C}$ partitioning was tested with a two-way ANOVA (R statistics, R Core Team, 2013). Thus the $\mathrm{C}$ partitioning reflects the amount of $\mathrm{C}$ from fresh assimilates remaining in a plant-soil compartment relative to the amount within the other compartments (and does not refer to a proportion of net $\mathrm{C}$ assimilation allocated into a plant tissue or soil compartment). As an alternative to assessing $\mathrm{C}$ partitioning, we tested the use of the ${ }^{13} \mathrm{C}$ peak amount (PL) and the amount of ${ }^{13} \mathrm{C}$ at the stationary level $(\mathrm{CL})$ for the
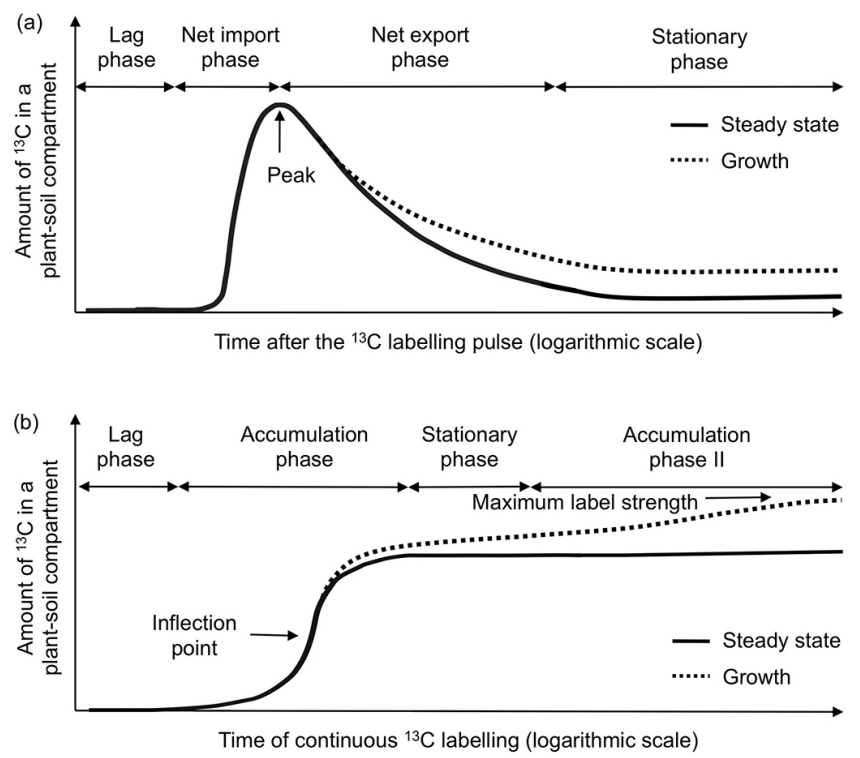

Fig. 1. Visualisation of the ${ }^{13} \mathrm{C}$ dynamics expected in plant-soil compartments after pulse labelling (a) or during continuous labelling (b) given for a system at steady state or at growth (change in pool size). The short-term dynamics can be described by three phases: (1) lag phase (time needed for $\mathrm{C}$ transfer), (2) phase dominated by ${ }^{13} \mathrm{C}$ import or net accumulation and (3) phase dominated by ${ }^{13} \mathrm{C}$ export or stationary phase (equilibrium between ${ }^{13} \mathrm{C}$ import and export). On the long-term a forth phase can be identified, which is characterized by stationary (pulse labelling) or increasing (continous labelling) ${ }^{13} \mathrm{C}$ contents.

calculation of the relative ${ }^{13} \mathrm{C}$ distribution between the single plant-soil compartments.

\subsubsection{C residence time}

The mean $\mathrm{C}$ residence time (MRT) is the time that a carbon atom remains on average in a compartment and is defined as the ratio of the holding capacity (pool size) and the (net) C flux through the pool. The MRT is assessed in tracer studies by measuring the changes in the label strength in a pool over time and deducing $\mathrm{C}$ fluxes by mathematical models fitted to the data points. We used R statistics (R Core Team, 2013) to fit the models by nonlinear least squares (function "nls"). The MRT was calculated as the inverse of the rate constant (MRT $=1 / k$ ) of the exponential model (Eq. 4) and the logistic model (Eq. 5) in the PL and CL, respectively. Thus, the rate constant in the PL is based only on the ${ }^{13} \mathrm{C}$ efflux, while in $\mathrm{CL}$ it is based on the net ${ }^{13} \mathrm{C}$ flux, making the latter more reasonable to estimate the $\mathrm{C}$ residence time as defined above. However, both models are only valid to describe one kinetic pool, with constant pool size (steady state) and proportional fluxes (first order kinetics).

$y=a \cdot e^{-k(t-b)}$ 
Table 1. $\delta^{13} \mathrm{C}$ signal detection in the plant-soil compartments. $\delta^{13} \mathrm{C}$ values \pm one standard deviation (in $\%$ ) of the plant tissues, microbial biomass (MB), soil organic matter (SOM) and the soil respiration (SR) are indicated for the five sampling dates (in days after the pulse or during the continuous labelling).

\begin{tabular}{llllll}
\hline \multirow{2}{*}{ Plant-soil } & \multicolumn{5}{c}{ Pulse labelling sampling dates (days) } \\
\cline { 2 - 6 } compartment & 0 & 0.1 & 2 & 8 \\
\hline Leaves & $-29.8( \pm 0.8)$ & $926.4^{*}( \pm 161.4)$ & $548.0^{*}( \pm 76.4)$ & $419.4^{*}( \pm 60.3)$ & $276.2^{*}( \pm 41.0)$ \\
Petioles & $-31.0( \pm 0.5)$ & $408.2^{*}( \pm 85.2)$ & $405.5^{*}( \pm 46.9)$ & $371.9^{*}( \pm 61.0)$ & $275.3^{*}( \pm 40.4)$ \\
Stems & $-30.8( \pm 0.1)$ & $418.8^{*}( \pm 90.5)$ & $461.3^{*}( \pm 54.0)$ & $480.3^{*}( \pm 58.1)$ & $331.0^{*}( \pm 66.0)$ \\
Cuttings & $-30.2( \pm 0.5)$ & $-26.7^{*}( \pm 1.5)$ & $-22.5^{*}( \pm 2.0)$ & $-22.9^{*}( \pm 2.8)$ & $-25.5( \pm 3.3)$ \\
Roots & $-30.5( \pm 1.6)$ & $-21.2( \pm 5.2)$ & $210.3^{*}( \pm 79.3)$ & $232.4^{*}( \pm 25.7)$ & $142.4^{*}( \pm 53.6)$ \\
MB & $-24.6( \pm 0.2)$ & $-24.4( \pm 0.3)$ & $-23.4( \pm 0.9)$ & $-23.7^{*}( \pm 0.4)$ & $-24.3( \pm 0.3)$ \\
SOM & $-27.5( \pm 0.0)$ & $-27.7( \pm 0.0)$ & $-27.6^{*}( \pm 0.0)$ & $-27.6( \pm 0.1)$ & $-27.5( \pm 0.2)$ \\
SR & $-27.8( \pm 1.3)$ & $-11.2( \pm 9.2)$ & $556.7( \pm 283.1)$ & $326.9^{*}( \pm 104.3)$ & $21.6^{*}( \pm 16.1)$ \\
\hline Plant-soil & & \multicolumn{1}{c}{ Continuous labelling sampling dates $($ days $)$} & \\
compartment & 0 & 2 & 8 & 14 \\
\hline Leaves & $-30.6( \pm 0.1)$ & $263.0^{*}( \pm 38.3)$ & $283.6^{*}( \pm 77.4)$ & $984.5^{*}( \pm 228.4)$ & $1122.6^{*}( \pm 140.6)$ \\
Petioles & $-32.8( \pm 0.2)$ & $163.9^{*}( \pm 56.2)$ & $212.8^{*}( \pm 75.2)$ & $908.5^{*}( \pm 277.3)$ & $941.9^{*}( \pm 292.7)$ \\
Stems & $-31.4( \pm 0.6)$ & $209.6^{*}( \pm 84.2)$ & $281.3^{*}( \pm 87.6)$ & $1093.7^{*}( \pm 402.2)$ & $1119.9^{*}( \pm 367.6)$ \\
Cuttings & $-31.2( \pm 0.3)$ & $-27.0^{*}( \pm 1.6)$ & $-26.9( \pm 1.9)$ & $-14.6( \pm 15.8)$ & $-14.5^{*}( \pm 2.1)$ \\
Roots & $-30.8( \pm 0.7)$ & $98.1^{*}( \pm 12.5)$ & $90.8( \pm 62.9)$ & $646.5( \pm 335.1)$ & $618.0( \pm 310.9)$ \\
MB & $-24.7( \pm 0.1)$ & $-24.1( \pm 0.4)$ & $-24.0( \pm 0.4)$ & $-21.1( \pm 4.1)$ & $-22.4( \pm 1.5)$ \\
SOM & $-28.0( \pm 0.1)$ & $-27.9( \pm 0.0)$ & $-27.8( \pm 0.2)$ & $-27.5( \pm 0.5)$ & $-27.5^{*}( \pm 0.2)$ \\
SR & $-27.5( \pm 0.8)$ & $96.0( \pm 71.7)$ & $148.4( \pm 71.6)$ & $504.5( \pm 280.6)$ & $491.5^{*}( \pm 160.2)$ \\
\hline
\end{tabular}

* Indicates a significant enrichment in ${ }^{13} \mathrm{C}(t$ test, $P<0.05)$ compared to the natural isotopic background (sampling date 0 days).

where $a$ is the amount of ${ }^{13} \mathrm{C}$ at the peak measured, $k$ is the rate constant of the tracer loss after the label peak (Fig. 1a, export phase), $t$ is the time after labelling and $b$ is time when the peak was detected.

$y=\frac{a}{1+e^{-k(t-b)}}$

where $a$ is the amount of ${ }^{13} \mathrm{C}$ at the stationary level (Fig. 1b), $k$ is the rate constant of the ${ }^{13} \mathrm{C}$ accumulation, $t$ is the time of labelling and $b$ is the time at the inflection point.

In addition we used the duration of the accumulation phase (CL) as an indicator for the $\mathrm{C}$ residence time. It is the time needed (after the time lag) to reach equilibrium between the ${ }^{13} \mathrm{C}$ import and export (Fig. 1b). The length of the accumulation phase was assessed by the time the derivative of the logistic curve $\left(\mathrm{mg}^{13} \mathrm{Cday}^{-1}\right)$ was less than $1 \%$ of the stationary level.

\section{Results and discussion}

\section{1 ${ }^{13} \mathrm{C}$ detection and distribution}

The fresh plant tissues (leaves, petioles, stems, roots) were enriched in ${ }^{13} \mathrm{C}$ by hundreds of per mil $\delta^{13} \mathrm{C}$ in both experiments (Table 1), indicating a substantial assimilation and incorporation of ${ }^{13} \mathrm{C}$. The variability of total ${ }^{13} \mathrm{C}$ assimilated was quite high between the plant replicates, reducing the significance of the isotopic enrichments measured. In the compartments with a large $\mathrm{C}$ pool (cuttings, microbial biomass, soil organic matter), the increase in $\delta^{13} \mathrm{C}$ signal was only a few per mil and it was mostly not statistically significant. The signal strength of the labelled assimilates was diluted by mixing with the present carbon pool, and in case of the PL, additionally by new unlabelled assimilates transferred to the plant-soil compartment, resulting in isotopic enrichments close to the IRMS detection limit in large $\mathrm{C}$ pools.

The expression of mass excess ${ }^{13} \mathrm{C}$ (Fig. 2) takes into account the present pool size and demonstrates the total amount of ${ }^{13} \mathrm{C}$ distributed in the plant-soil system. After pulse labelling, the leaves showed the highest peak in ${ }^{13} \mathrm{C}$ $(13.7 \pm 2.1 \mathrm{mg})$, followed by the stems $(3.2 \pm 0.9 \mathrm{mg})$, the cuttings $(0.9 \pm 0.2 \mathrm{mg})$, the petioles $(0.7 \pm 0.2 \mathrm{mg})$ and the roots $(0.4 \pm 0.1 \mathrm{mg})$. Even in the microbial biomass a small label peak could be observed $(0.02 \pm 0.01 \mathrm{mg})$ in parallel to the peak in the soil ${ }^{13} \mathrm{CO}_{2}$ efflux $\left(0.39 \pm 0.22 \mathrm{mg} \mathrm{day}^{-1}\right)$. The same distribution pattern was detected in the continuous labelling experiment. After 14 days of labelling $19.6 \pm 5.8 \mathrm{mg}{ }^{13} \mathrm{C}$ was recovered in the leaves, $7.7 \pm 3.5 \mathrm{mg}$ in the stems, $2.0+0.7 \mathrm{mg}$ in the petioles, $1.5+0.5 \mathrm{mg}$ in the cuttings, $0.8 \pm 0.5 \mathrm{mg}$ in the roots, $0.05 \pm 0.03$ in the microbial biomass and $0.32 \pm 0.11 \mathrm{mg}^{13} \mathrm{C} \mathrm{day}^{-1}$ was respired belowground. 

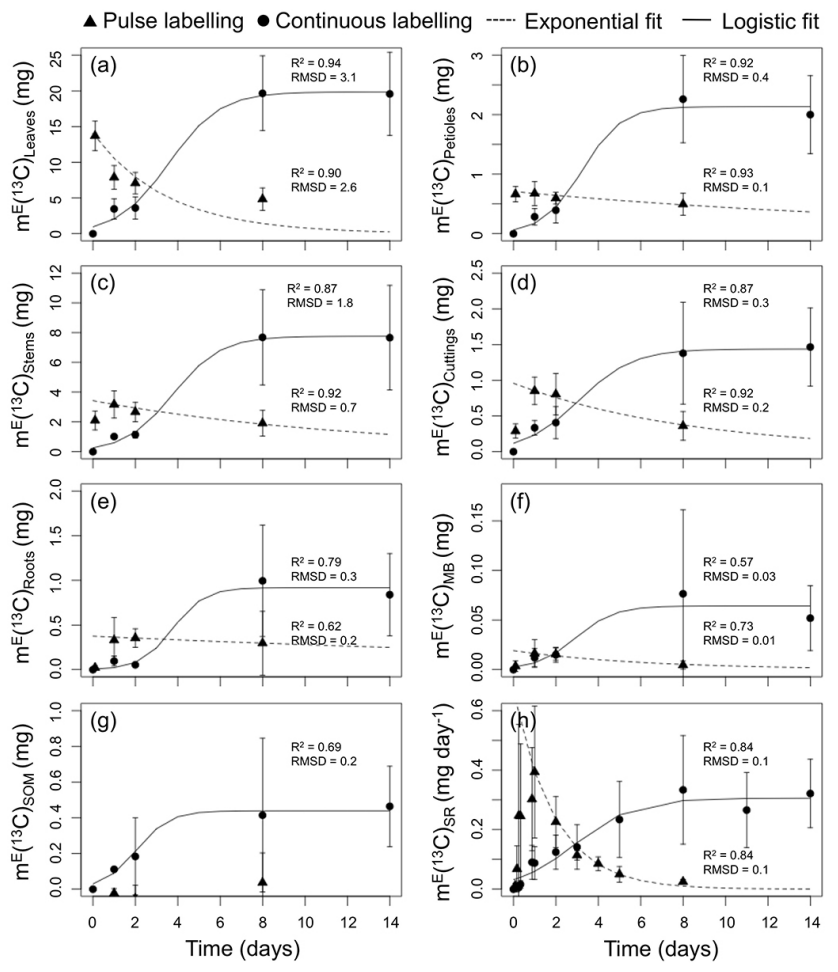

Fig. 2. Dynamics in the ${ }^{13} \mathrm{C}$ distribution. ${ }^{13} \mathrm{C}$ label recovered after the pulse and during the continuous exposure of the plants to ${ }^{13} \mathrm{CO}_{2}$ in leaves (a), petioles (b), stems (c), cuttings (d), roots (e), microbial biomass MB (f), soil organic matter SOM (g) and in the soil respiration SR (h) expressed as mass of ${ }^{13} \mathrm{C}$ in excess $m^{\mathrm{E}}\left(\mathrm{mg}{ }^{13} \mathrm{C}\right.$ and $\mathrm{mg}^{13} \mathrm{C} \mathrm{day}^{-1}$ ). Error bars indicate \pm one standard deviation of the three plant individuals. The best fits (nonlinear least squares) are given for the exponential function after pulse labelling and for the logistic increase during continuous labelling. The coefficient of determination $\left(R^{2}\right)$ and the root-mean-square-deviation (RMSD) were calculated with the individual measurement points. A sensitivity analysis of the logistic model fit can be found in the Supplement.

\subsection{C transfer time}

The soil respiration was significantly enriched in ${ }^{13} \mathrm{C}$ within five hours after pulse labelling and nine hours after the continuous labelling started. Such a fast minimum $\mathrm{C}$ transfer time from the leaves to the soil has already been reported for young poplars (Horwath et al., 1994) and other tree seedlings (Barthel et al., 2011; Pumpanen et al., 2008). The individual plant-soil compartments were enriched in ${ }^{13} \mathrm{C}$ already on the first sampling date. Hence we missed the lag time to the specific compartments due to the low sampling frequency of the destructive harvests. The delay in the signal detection in the CL compared to the PL is due to the weaker label strength of the fresh assimilates (10 atom $\%$ vs. 99 atom $\%{ }^{13} \mathrm{C}$ in the $\mathrm{PL}$ ). The same amount of labelled assimilates transferred into a compartment yields a lower signal in the CL than in the PL and as a result more time is needed until the lower detection limit is reached. The minimum $\mathrm{C}$ transfer times measured by the PL and CL technique are therefore not directly comparable.

The mean transfer times (Table 2, parameter $b$ ) were two days shorter in the PL (0-2 days) than in the CL experiment (2-4 days). In the PL experiment, the mean transfer time increased with the distance to the assimilating leaves, e.g. it was one day in the aboveground plant tissues and two days in the roots. Thus the mean transfer time assessed by the label peak in PL reflects mainly the minimum transfer time of the labelled assimilates from the leaves to the other plantsoil compartments, due to a preferential labelling of labile compounds with PL (Meharg, 1994). By contrast, the mean transfer times assessed by CL are the shortest in the belowground soil compartments (SOM, microbial biomass) and the longest in the stems, roots and leaves, which are the plant organs known to store most C (Barbaroux et al., 2003). This indicates that continuous labelling leads to a more homogeneous labelling, including transient $\mathrm{C}$ storage pools, extending the mean transfer time by two days compared to the observation in the PL experiment. Thus the mean transfer time assessed by the inflection point in the CL experiment is rather an indicator for the $\mathrm{C}$ transfer through the compartment (short-term $\mathrm{C}$ cycling) than into the compartment (C transfer from other tissues).

\subsection{C partitioning}

The patterns of the relative ${ }^{13} \mathrm{C}$ distribution within the plantsoil compartments obtained by the two labelling techniques were similar throughout and equivalent at the end of the experiments (Table 3). The differences in the proportion of $\mathrm{C}$ allocated into the plant-soil compartments at the specific sampling dates were up to $6.6 \%$ between the two labelling techniques (Table 3), as for example in the leaves and stems at sampling date one. However, the only significant difference observed was a slightly higher allocation to the petioles $(+0.2-1.7 \%)$ and to the microbial biomass $(+0.1 \%)$ with CL compared to PL. The results of the last destructive sampling reveal that most of the assimilated $\mathrm{C}$ remained in the leaves $(62.5 \pm 0.5 \%)$, followed by the stems $(23.4 \pm 0.1 \%)$, petioles $(6.3 \pm 0.1 \%)$, cuttings $(4.7 \pm 0.1 \%)$, roots $(2.9 \pm 0.6 \%)$ and microbial biomass $(0.1 \pm 0.1 \%)$. Thus the bigger part ( $>90 \%$ ) of net assimilated $\mathrm{C}$ was recovered in the aboveground plant tissues. We assume that the dominant allocation into leaf biomass was promoted by the low light availability in the climate chambers, which was limiting for $\mathrm{C}$ assimilation, and by the high soil water and nutrient availability in the pots, reducing the need for root production. Increased shoot vs. root allocation has been observed in poplar trees grown under high $\mathrm{N}$ and water availability (Coleman et al., 2004; Pregitzer et al., 1990) or under light limitation in the understorey (Landhäusser and Lieffers, 2001) before.

The time of sampling had, like the labelling approach, a minor effect on the results of the $\mathrm{C}$ partitioning in the plantsoil compartments (Table 3). Between the sampling on the 
Table 2. Parameters $(a, b, k)$ of the exponential and the logistic model used to describe the ${ }^{13} \mathrm{C}$ dynamics in the pulse (PL) and continuous (CL) labelling, respectively. Parameter $a$ is the total amount of ${ }^{13} \mathrm{C}(\mathrm{mg})$ at the signal peak (PL) or at the stationary level (CL), parameter $b$ marks the time of the signal peak (PL) or the time of inflection (CL) and parameter $k$ is the rate constant describing the decrease (PL) and increase (CL) of the ${ }^{13} \mathrm{C}$ abundance in a compartment, which is the basis for the mean residence time (MRT) calculation.

\begin{tabular}{|c|c|c|c|c|c|c|c|c|c|}
\hline \multirow[b]{2}{*}{$\begin{array}{l}\text { Plant-soil } \\
\text { compartment }\end{array}$} & \multicolumn{4}{|c|}{ Pulse labelling, exponential model } & \multicolumn{5}{|c|}{ Continuous labelling, logistic model } \\
\hline & $\begin{array}{l}\text { Peak, amount } \\
\text { (mg }{ }^{13} \mathrm{C} \\
\text { (fraction of total)) } \\
\text { (a) }\end{array}$ & $\begin{array}{l}\text { Peak, } \\
\text { time } \\
\text { (days) } \\
(b)\end{array}$ & $\begin{array}{l}\text { Rate } \\
\text { constant } \\
(k)\end{array}$ & $\begin{array}{l}\text { MRT } \\
\text { (days) } \\
(1 / k)\end{array}$ & $\begin{array}{l}\text { Stationary level, } \\
\text { amount (mg }{ }^{13} \mathrm{C} \\
\text { (fraction of total)) } \\
\text { (a) }\end{array}$ & $\begin{array}{l}\text { Inflection, } \\
\text { time } \\
\text { (days) } \\
(b)\end{array}$ & $\begin{array}{l}\text { Rate } \\
\text { constant } \\
(k)\end{array}$ & $\begin{array}{l}\text { MRT } \\
\text { (days) }\end{array}$ & $\begin{array}{l}\text { Stationary } \\
\text { level, } \\
\text { time } \\
\text { (days) }\end{array}$ \\
\hline Leaves & $13.70(73 \%)$ & 0.1 & 0.286 & 3.5 & $19.85(62 \%)$ & 3.6 & 0.83 & 1.2 & 7.2 \\
\hline Petioles & $0.68(4 \%)$ & 1 & 0.047 & 21.1 & $2.14(7 \%)$ & 3.3 & 1.08 & 0.9 & 6.5 \\
\hline Stems & $3.17(17 \%)$ & 1 & 0.077 & 13.0 & $7.76(24 \%)$ & 3.8 & 0.89 & 1.1 & 7.6 \\
\hline Cuttings & $0.85(5 \%)$ & 1 & 0.118 & 8.5 & $1.44(4 \%)$ & 3.1 & 0.78 & 1.3 & 6.2 \\
\hline Roots & $0.35(2 \%)$ & 2 & 0.029 & 34.0 & $0.92(3 \%)$ & 3.8 & 1.33 & 0.8 & 7.6 \\
\hline MB & $0.02(0 \%)$ & 1 & 0.179 & 5.6 & $0.06(0 \%)$ & 2.9 & 1.10 & 0.9 & 5.9 \\
\hline SOM & & & & & 0.44 & 2.1 & 1.29 & 0.8 & 4.2 \\
\hline SR & 0.39 & 1 & 0.520 & 1.9 & 0.31 & 2.9 & 0.73 & 1.4 & 5.9 \\
\hline
\end{tabular}

Table 3. Estimation of $\mathrm{C}$ partitioning between plant and soil compartments indicated by the relative ${ }^{13} \mathrm{C}$ distribution (in $\%$ ) and for the different sampling dates after pulse and during continuous labelling ( \pm one standard deviation is indicated in brackets). The effects of labelling technique ("labelling") and sampling date ("sampling") were tested for the sampling dates in common (1, 2 and 8 days) by two-way analysis of variance (ANOVA).

\begin{tabular}{|c|c|c|c|c|c|c|c|c|c|c|}
\hline \multirow[t]{2}{*}{$\begin{array}{l}\text { Plant-soil } \\
\text { compartment }\end{array}$} & \multicolumn{4}{|c|}{$\begin{array}{c}\text { Pulse labelling } \\
\text { Sampling dates (days) }\end{array}$} & \multicolumn{4}{|c|}{$\begin{array}{l}\text { Continuous labelling } \\
\text { Sampling dates (days) }\end{array}$} & \multicolumn{2}{|c|}{$\begin{array}{c}\text { Significance level } P \\
\text { (Sampling date } 1,2,8)\end{array}$} \\
\hline & 0 & 1 & 2 & 8 & 1 & 2 & 8 & 14 & Labelling & Sampling \\
\hline Leaves & $\begin{array}{l}81.9 \\
( \pm 2.0)\end{array}$ & $\begin{array}{l}61.2 \\
( \pm 3.1)\end{array}$ & $\begin{array}{l}61.6 \\
( \pm 1.9)\end{array}$ & $\begin{array}{l}62.2 \\
( \pm 4.2)\end{array}$ & $\begin{array}{l}67.8 \\
( \pm 4.3)\end{array}$ & $\begin{array}{l}65.4 \\
( \pm 3.7)\end{array}$ & $\begin{array}{l}62.3 \\
( \pm 3.9)\end{array}$ & $\begin{array}{l}62.9 \\
( \pm 4.6)\end{array}$ & 0.053 & 0.317 \\
\hline Petioles & $\begin{array}{l}4.0 \\
( \pm 0.4)\end{array}$ & $\begin{array}{l}5.2 \\
( \pm 0.7)\end{array}$ & $\begin{array}{l}5.2 \\
( \pm 0.5)\end{array}$ & $\begin{array}{l}6.3 \\
( \pm 0.1)\end{array}$ & $\begin{array}{l}5.4 \\
( \pm 0.8)\end{array}$ & $\begin{array}{l}6.9 \\
( \pm 0.5)\end{array}$ & $\begin{array}{l}7.1 \\
( \pm 0.1)\end{array}$ & $\begin{array}{l}6.4 \\
( \pm 0.5)\end{array}$ & $0.014^{*}$ & $0.006^{* *}$ \\
\hline Stems & $\begin{array}{l}12.3 \\
( \pm 1.8)\end{array}$ & $\begin{array}{l}24.4 \\
( \pm 4.1)\end{array}$ & $\begin{array}{l}23.2 \\
( \pm 2.5)\end{array}$ & $\begin{array}{l}23.5 \\
( \pm 3.8)\end{array}$ & $\begin{array}{l}17.8 \\
( \pm 5.8)\end{array}$ & $\begin{array}{l}19.0 \\
( \pm 4.8)\end{array}$ & $\begin{array}{l}23.4 \\
( \pm 2.9)\end{array}$ & $\begin{array}{l}23.4 \\
( \pm 3.7)\end{array}$ & 0.064 & 0.253 \\
\hline Cuttings & $\begin{array}{l}1.7 \\
( \pm 0.3)\end{array}$ & $\begin{array}{l}6.6 \\
( \pm 0.3)\end{array}$ & $\begin{array}{l}6.8 \\
( \pm 1.2)\end{array}$ & $\begin{array}{l}4.6 \\
( \pm 1.7)\end{array}$ & $\begin{array}{l}6.9 \\
( \pm 1.5)\end{array}$ & $\begin{array}{l}7.3 \\
( \pm 2.1)\end{array}$ & $\begin{array}{l}4.2 \\
( \pm 1.0)\end{array}$ & $\begin{array}{l}4.7 \\
( \pm 0.9)\end{array}$ & 0.875 & $0.003^{* *}$ \\
\hline Roots & $\begin{array}{l}0.1 \\
( \pm 0.1)\end{array}$ & $\begin{array}{l}2.4 \\
( \pm 1.4)\end{array}$ & $\begin{array}{l}3.0 \\
( \pm 0.3)\end{array}$ & $\begin{array}{l}3.4 \\
( \pm 3.1)\end{array}$ & $\begin{array}{l}1.9 \\
( \pm 0.8)\end{array}$ & $\begin{array}{l}1.1 \\
( \pm 0.6)\end{array}$ & $\begin{array}{l}2.8 \\
( \pm 1.2)\end{array}$ & $\begin{array}{l}2.5 \\
( \pm 0.8)\end{array}$ & 0.184 & 0.215 \\
\hline $\begin{array}{l}\text { Microbial } \\
\text { biomass }\end{array}$ & $\begin{array}{l}0.0 \\
( \pm 0.0)\end{array}$ & $\begin{array}{l}0.1 \\
( \pm 0.1)\end{array}$ & $\begin{array}{l}0.1 \\
( \pm 0.0)\end{array}$ & $\begin{array}{l}0.1 \\
( \pm 0.0)\end{array}$ & $\begin{array}{l}0.2 \\
( \pm 0.1)\end{array}$ & $\begin{array}{l}0.3 \\
( \pm 0.2)\end{array}$ & $\begin{array}{l}0.2 \\
( \pm 0.2)\end{array}$ & $\begin{array}{l}0.2 \\
( \pm 0.1)\end{array}$ & $0.032^{*}$ & 0.438 \\
\hline
\end{tabular}

No significant interaction effect was detected between the independent variables. The significance levels indicated are $P<0.05(*)$ and $P<0.01(* *)$.

first day and day eight, a significant difference was observed in the petioles $(+1.4 \%)$ and the cuttings $(-2.3 \%)$, but the changes in all other plant-soil compartments were not significant. In contrast, the $\mathrm{C}$ partitioning observed directly after PL (0.1 days) was largely different. The allocation into the leaves was overestimated by approximately $20 \%$ compared to the following sampling dates. Similarly, a trend of increased $\mathrm{C}$ allocation into the leaves (by $5 \%$ ) at the early sampling dates can be observed in the CL experiment. The overestimation of the $\mathrm{C}$ allocation to leaves within the first days of labelling or directly after pulse labelling is due to the time lag in tracer distribution. As shown in the previous section, the mean ${ }^{13} \mathrm{C}$ transfer time from leaves to roots was two days in the PL, and the data from the CL indicates, that a steady state between tracer import and export in the plant compartments was reached approximately after six days (discussed in the next section).

To assess the belowground $\mathrm{C}$ partitioning, the time of sampling is of much greater importance (Table 4). At the end of the experiments, $13.3 \pm 1.3 \%$ of the ${ }^{13} \mathrm{C}$ recovered was detected belowground. Most of it was released as $\mathrm{CO}_{2}$ $(81.2 \pm 0.9 \%)$, and a small amount remained in the root $(18.0 \pm 0.3 \%)$ and microbial biomass $(0.7 \pm 0.6 \%)$. The results obtained at a specific sampling date are similar for the 
Table 4. Estimation of belowground $\mathrm{C}$ partitioning indicated by the relative ${ }^{13} \mathrm{C}$ distribution (in $\%$ ) between belowground pools and fluxes measured at different sampling dates after pulse and during continuous labelling ( \pm one standard deviation is indicated in brackets). The effects of labelling technique ("labelling") and sampling date ("sampling") were tested for the sampling dates in common (1, 2 and 8 days) by two-way analysis of variance (ANOVA).

\begin{tabular}{|c|c|c|c|c|c|c|c|c|c|c|}
\hline \multirow[t]{2}{*}{$\begin{array}{l}\text { Belowground } \\
\text { C pool/flux }\end{array}$} & \multicolumn{4}{|c|}{$\begin{array}{c}\text { Pulse labelling } \\
\text { Sampling dates (days) }\end{array}$} & \multicolumn{4}{|c|}{$\begin{array}{l}\text { Continuous labelling } \\
\text { Sampling dates (days) }\end{array}$} & \multicolumn{2}{|c|}{$\begin{array}{c}\text { Significance level } P \\
\text { (Sampling date } 1,2,8)\end{array}$} \\
\hline & 0 & 1 & 2 & 8 & 1 & 2 & 8 & 14 & Labelling & Sampling \\
\hline Roots & $\begin{array}{l}74.8 \\
( \pm 21.5)\end{array}$ & $\begin{array}{l}57.2 \\
( \pm 1.7)\end{array}$ & $\begin{array}{l}42.5 \\
( \pm 9.9)\end{array}$ & $\begin{array}{l}17.8 \\
( \pm 11.9)\end{array}$ & $\begin{array}{l}64.7 \\
( \pm 13.5)\end{array}$ & $\begin{array}{l}31.0 \\
( \pm 9.2)\end{array}$ & $\begin{array}{l}35.0 \\
( \pm 10.4)\end{array}$ & $\begin{array}{l}18.2 \\
( \pm 5.4)\end{array}$ & 0.523 & $0.004^{* *}$ \\
\hline $\begin{array}{l}\text { Microbial } \\
\text { biomass }\end{array}$ & $\begin{array}{l}15.0 \\
( \pm 22.4)\end{array}$ & $\begin{array}{l}2.7 \\
( \pm 0.5)\end{array}$ & $\begin{array}{l}1.9 \\
( \pm 0.9)\end{array}$ & $\begin{array}{l}0.3 \\
( \pm 0.2)\end{array}$ & $\begin{array}{l}7.2 \\
( \pm 3.7)\end{array}$ & $\begin{array}{l}8.6 \\
( \pm 5.7)\end{array}$ & $\begin{array}{l}2.4 \\
( \pm 11.0)\end{array}$ & $\begin{array}{l}1.2 \\
( \pm 5.2)\end{array}$ & $0.005^{* *}$ & $0.019^{*}$ \\
\hline $\begin{array}{l}\text { Soil } \mathrm{CO}_{2} \\
\text { efflux }\end{array}$ & $\begin{array}{l}10.2 \\
( \pm 13.5)\end{array}$ & $\begin{array}{l}40.1 \\
( \pm 2.2)\end{array}$ & $\begin{array}{l}55.6 \\
( \pm 10.8)\end{array}$ & $\begin{array}{l}81.9 \\
( \pm 12.0)\end{array}$ & $\begin{array}{l}28.1 \\
( \pm 12.7)\end{array}$ & $\begin{array}{l}60.4 \\
( \pm 11.5)\end{array}$ & $\begin{array}{l}62.6 \\
( \pm 11.0)\end{array}$ & $\begin{array}{l}80.6 \\
( \pm 5.2)\end{array}$ & 0.208 & $0.001^{* *}$ \\
\hline
\end{tabular}

No significant interaction effect was detected between the independent variables. The significance levels indicated are $P<0.05\left(^{*}\right)$ and $P<0.01(* *)$.

two labelling techniques, except for the generally higher proportion of ${ }^{13} \mathrm{C}$ detected in the microbial biomass with CL. However, the results at the different sampling dates were very distinct. At the early sampling dates, the estimated $\mathrm{C}$ allocation to roots was more expressed or even dominating (43-75\% in the PL and 31-65\% in the CL). This might be due to a time lag in the tracer distribution at the plant-soil interface. As discussed above, the first labelled assimilates were detected belowground within a few hours. However, much more time (6-8 days) was needed to reach an equilibrium (stationary state) in the belowground $\mathrm{C}$ fluxes (Table 2). This is inline with the one week allocation time proposed by Warembourg and Estelrich (2000) and the time delay of 56 days in the steady labelling of root exudation observed by Thornton et al. (2004). Accordingly, a time lag between the label strength in the roots and the rhizomicrobial respiration might have caused the underestimation of the proportion of respired $\mathrm{C}$ to total belowground $\mathrm{C}$ at the beginning of the experiment.

Another way to estimate the $\mathrm{C}$ partitioning between the plant-soil compartments independent of the sampling time, is the use of the amount of ${ }^{13} \mathrm{C}$ at the label peak or the stationary level, i.e. by the parameter "a" of the exponential and logistic model, respectively (Table 2). The estimation in the CL matches the above-mentioned average values of $\mathrm{C}$ partitioning. The differences are less than $1 \%$ in the compartments. But the results of the relative amount at the label peaks in PL overestimate the allocation to the leaves $(73.0 \%)$ and underestimate the allocation to petioles (3.6\%) and stems $(16.9 \%)$. This might be due to a lack in label peak detection. The leaves were sampled directly after labelling, while the next sampling date was one day later. The peak in the petioles and stems might have occurred in between and thus the peak amount could have been underestimated.

\subsection{C residence time}

The estimates of the mean residence time (MRT) assessed by the rate constant $(k)$ of the exponential and logistic function (Fig. 2) of the PL experiment are higher than the one of the CL experiment (Table 2). In the PL experiment, the longest MRT was detected in roots ( 34 days), then the MRT decreased in the order of petioles (21 days), stems (13 days), cuttings ( 9 days), microbial biomass (6 days) and leaves ( 3 days). These residence times are in the range of values reported in literature. For example, mean residence times of 16-41 days have been reported for fine roots (Keel et al., 2012), 3.2 days for the total microbial biomass (Yevdokimov et al., 2007) and 2.4 days for leaves of beech seedling (Ruehr et al., 2009). In the CL experiment, the MRTs were around one day in all plant-soil compartments. The cuttings, leaves and stems had the highest MRT (1.1-1.3 days), followed by the petioles and microbial biomass ( 0.9 days) and the lowest MRTs were detected in the roots and SOM (0.8 days).

The large differences in the MRTs obtained by the two labelling techniques are probably due to the strong assumptions of the simple exponential and logistic models applied, which do not match reality. The mathematical models applied describe the dynamics in a single pool, whereas plant tissues and the soil organic matter consist of several $\mathrm{C}$ pools (e.g. labile and structural). Investigating the $\mathrm{C}$ allocation and turnover in specific plant or soil $\mathrm{C}$ pools requires a more complex modelling (e.g. as in Kuzyakov et al., 1999; Street et al., 2011; Streit et al., 2012).

One assumption of the simple exponential decay and logistic growth model is constant pool size (steady state). In this study, as in many other labelling studies with young plants, the plant-soil system was not at a steady state, but characterised by plant growth. Under such conditions the accumulation of ${ }^{13} \mathrm{C}$ in the structural pool is enlarged and the ${ }^{13} \mathrm{C}$ export (detected by the decay model in PL studies) is reduced (Fig. 1a). This leads to an underestimation of the decline rates 
and thus to an overestimation of the MRTs assessed by the PL technique (results of a model including a non-zero asymptote to account for growth are given in the Supplement). The logistic model of the CL technique is more robust regarding the steady state assumption, since the whole transition and not only the export phase is analysed. However, if the system is not at steady state, the rate constant tends to be overestimated and consequently the MRT underestimated (Supplement).

Another assumption of the exponential decay model of the $\mathrm{PL}$ technique is that the dynamics are governed by ${ }^{13} \mathrm{C}$ efflux, but it has been shown that remobilisation of stored ${ }^{13} \mathrm{C}$ is leading to ${ }^{13} \mathrm{C}$ influx even after the signal peak (Barthel et al., 2011; Endrulat et al., 2010; Epron et al., 2011). This is particularly relevant for compartments which are farther away from the assimilating leaves and are characterised by a broad label peak (e.g. in roots, microbial biomass). The prolonged import of ${ }^{13} \mathrm{C}$ even after the signal peak leads to the underestimation of the decline rate. Therefore we can assume that especially the MRTs of the belowground compartments are overestimated with the PL technique.

As an alternative to the rate constant $(k)$, the length of the accumulation phase (in the CL) can be used to estimate the mean $\mathrm{C}$ residence time (Fig. 1b). It reflects the time between first label appearance and steady state of the ${ }^{13} \mathrm{C}$ import and export of a compartment. In the present study this residence time was 4-8 days in the different plant-soil compartments (Table 2). The longest residence time was estimated for the roots and stems (7.6 days), followed by the leaves (7.2 days), petioles (6.5 days), cuttings ( 6.2 days), microbial biomass and soil respiration (5.9 days) and in the SOM (4.2 days). We think that this estimation of the $\mathrm{C}$ residence time is the most reasonable, since it is not based on the assumptions described above. However, we would expect a longer residence time in the SOM than in the microbial biomass. The poor estimation of the SOM MRT is caused by the low enrichment detected, which was close to the detection limit and therefore not significant.

\subsection{Comparisons of techniques}

The pulse labelling technique is most suitable to detect the minimum $\mathrm{C}$ transfer time from the leaves to the roots. The complete labelling of the fresh assimilates facilitates a fast signal detection in the plant compartments. However, the amount of assimilates labelled during the relatively short labelling period is not sufficient to achieve a detectable signal in large $\mathrm{C}$ pools, such as the soil organic matter. Consequently the investigation of $\mathrm{C}$ partitioning and $\mathrm{C}$ residence time is restricted to those pools, which allow a clear signal detection (e.g. at least twice the magnitude of the background noise). A further disadvantage of the pulse labelling technique is, that the key parameter to consider is the decline of the ${ }^{13} \mathrm{C}$ signal. Thus the estimation of $\mathrm{C}$ allocation is based on what remains in a compartment (and not on what is allocated to it). The calculation of the mean residence time by simple exponential or logistic models are based on the assumption that the system is at steady state, but such conditions hardly exist in nature. Thus the calculation of the mean residence time based on the rate constant of the exponential model provides at best an approximation (as it is the case for the logistic model in continuous labelling experiments).

Continuous labelling labels the compounds not as strongly, but for longer durations and more homogeneously. Therefore this technique has the potential to detect ${ }^{13} \mathrm{C}$ dynamics (allocation priorities) in all plant-soil compartments, and can be applied to determine even large $\mathrm{C}$ pools. The parameters of the logistic model used to describe the tracer dynamics lead to more specific information on $\mathrm{C}$ cycling. The time lag is an indicator for the minimum transfer time, however its assessment is poorer than with the PL technique. The time of inflection (minus the lag time) marks the mean $\mathrm{C}$ transfer time through a compartment and thus illustrates the shortterm $\mathrm{C}$ cycling including transient storage pools. The length of the accumulation phase is an indicator for the mean $\mathrm{C}$ residence time in a compartment and the level of the steady state reflects the amount of $\mathrm{C}$ allocated into it.

\section{Conclusions}

The $\mathrm{C}$ transfer time, $\mathrm{C}$ partitioning and $\mathrm{C}$ residence time can be assessed with both labelling techniques. The results of the $\mathrm{C}$ transfer time of fresh assimilates from the leaves, through the plant and to the belowground compartments are not comparable for the two techniques. Pulse labelling is better suited to assess the minimum transfer time. However, PL is restricted to small $\mathrm{C}$ pools, due to the dilution of the tracer signal in large $\mathrm{C}$ pools.

The plant-soil C partitioning pattern obtained by the PL and CL technique are comparable, but the time of sampling is crucial. One has to account for the time lag in $\mathrm{C}$ transfer from the leaves to other compartments and for the residence time of the $\mathrm{C}$ within them. In the current study on young poplar trees, 4-8 days were required for the homogeneous labelling of the ${ }^{13} \mathrm{C}$ import and export in order to obtain consistent results of $\mathrm{C}$ partitioning.

The simple exponential and logistic models used to assess the $\mathrm{C}$ mean residence times are based on assumptions of constant pool size and proportional fluxes. These assumptions are, as in this study, often not appropriate. The logistic model (accumulation phase) is better suited to obtain estimates of the mean residence time in systems at non-steady state (e.g. during plant growth). The application of the logistic model to describe the distribution of the ${ }^{13} \mathrm{C}$ in continuous labelling studies would have to be further evaluated in new experiments and in existing datasets.

\section{Supplementary material related to this article is available online at http://www.biogeosciences.net/11/ 1637/2014/bg-11-1637-2014-supplement.pdf.}


Acknowledgements. This study was funded by the Swiss National Science Foundation (project number 135233). We thank the members of the Soil Science and Biogeochemistry (University of Zurich, UZH) and of the Ecosystem Fluxes (Paul Scherrer Institute, PSI) research group for valuable discussions. Especially we thank I. Lötscher (PSI), I. Woodhatch (UZH), R. Maier (UZH) and R. Künzli (DMP Ltd) for technical assistance.

Edited by: U. Seibt

\section{References}

Amelung, W., Brodowski, S., Sandhage-Hofmann, A., and Bol, R.: Combining biomarker with stable isotope analyses for assessing the transformation and turnover of soil organic matter, Adv. Agron., 100, 155-250, 2008.

Barbaroux, C., Bréda, N., and Dufrêne, E.: Distribution of aboveground and below-ground carbohydrate reserves in adult trees of two contrasting broad-leaved species (Quercus petraea and Fagus sylvatica), New Phytol., 157, 605-615, 2003.

Barthel, M., Hammerle, A., Sturm, P., Baur, T., Gentsch, L., and Knohl, A.: The diel imprint of leaf metabolism on the $\delta^{13} \mathrm{C}$ signal of soil respiration under control and drought conditions, New Phytol., 192, 925-938, 2011.

Bonvehi, J. S., Jorda, R. E., and Jaen, J. A.: The ripening process of kiwifruits (Actinidia deliciosa) grown in Catalonia, Spain, J. Food Quality, 20, 371-380, 1997.

Bowling, D. R., Pataki, D. E., and Randerson, J. T.: Carbon isotopes in terrestrial ecosystem pools and $\mathrm{CO}_{2}$ fluxes, New Phytol., 178, 24-40, 2008.

Brand, W. A. and Coplen, T. B.: Stable isotope deltas: tiny, yet robust signatures in nature, Isot. Environ. Healt. S., 48, 393-409, 2012

Brüggemann, N., Gessler, A., Kayler, Z., Keel, S. G., Badeck, F., Barthel, M., Boeckx, P., Buchmann, N., Brugnoli, E., Esperschütz, J., Gavrichkova, O., Ghashghaie, J., Gomez-Casanovas, N., Keitel, C., Knohl, A., Kuptz, D., Palacio, S., Salmon, Y., Uchida, Y., and Bahn, M.: Carbon allocation and carbon isotope fluxes in the plant-soil-atmosphere continuum: a review, Biogeosciences, 8, 3457-3489, doi:10.5194/bg-8-3457-2011, 2011.

Coleman, M. D., Friend, A. L., and Kern, C. C.: Carbon allocation and nitrogen acquisition in a developing Populus deltoides plantation, Tree Physiol., 24, 1347-1357, 2004.

Coplen, T. B.: Guidelines and recommended terms for expression of stable-isotope-ratio and gas-ratio measurement results, Rapid Commun. Mass Sp., 25, 2538-2560, 2011.

Dawson, T. E., Mambelli, S., Plamboeck, A. H., Templer, P. H., and Tu, K. P.: Stable isotopes in plant ecology, Annu. Rev. Ecol. Syst., 33, 507-559, 2002.

Endrulat, T., Saurer, M., Buchmann, N. and Brunner, I.: Incorporation and remobilization of ${ }^{13} \mathrm{C}$ within the fine-root systems of individual Abies alba trees in a temperate coniferous stand, Tree Physiol., 30, 1515-1527, 2010.

Epron, D., Ngao, J., Dannoura, M., Bakker, M. R., Zeller, B., Bazot, S., Bosc, A., Plain, C., Lata, J. C., Priault, P., Barthes, L., and Loustau, D.: Seasonal variations of belowground carbon transfer assessed by in situ ${ }^{13} \mathrm{CO}_{2}$ pulse labelling of trees, Biogeosciences, 8, 1153-1168, doi:10.5194/bg-8-1153-2011, 2011.
Epron, D., Bahn, M., Derrien, D., Lattanzi, F. A., Pumpanen, J. S., Gessler, A., Högberg, P., Maillard, P., Dannoura, M., Gérant, D., and Buchmann, N.: Pulse-labelling trees to study carbon allocation dynamics: a review of methods, current knowledge and future prospects, Tree Physiol., 32, 776-798, 2012.

Esperschütz, J., Gattinger, A., Buegger, F., Lang, H., Munch, J. C., Schloter, M., and Winkler, J. B.: A continuous labelling approach to recover photosynthetically fixed carbon in plant tissue and rhizosphere organisms of young beech trees (Fagus sylvatica L.) using ${ }^{13} \mathrm{C}$ depleted $\mathrm{CO}_{2}$, Plant Soil, 323, 21-29, 2009.

Glaser, B.: Compound-specific stable-isotope $\left(\delta^{13} \mathrm{C}\right)$ analysis in soil science, J. Plant Nutr. Soil Sc., 168, 633-648, 2005.

Grams, T. E. E., Werner, H., Kuptz, D., Ritter, W., Fleischmann, F., Andersen, C. P., and Matyssek, R.: A free-air system for longterm stable carbon isotope labeling of adult forest trees, Trees, 25, 187-198, 2010.

Gutierrez-Gonzalez, J. J., Wise, M. L., and Garvin, D. F.: A developmental profile of tocol accumulation in oat seeds, J. Cereal Sc., 57, 79-83, 2013.

Horwath, W. R., Pregitzer, K. S., and Paul, E. A.: ${ }^{14} \mathrm{C}$ allocation in tree-soil systems, Tree Physiol., 14, 1163-1176, 1994.

Iwahashi, M., Tachibana, Y., and Ohta, Y.: Accumulation of calcium, magnesium, potassium and sodium with growth of individual leaves, petioles and stems of cucumber plants, Soil Sci. Plant Nutr., 28, 441-449, 1982.

Joergensen, R.: The fumigation-extraction method to estimate soil microbial biomass: Calibration of the $k_{\mathrm{EC}}$ value, Soil Biol. Biochem., 28, 25-31, 1996.

Keel, S. G., Siegwolf, R. T. W., and Körner, C.: Canopy $\mathrm{CO}_{2}$ enrichment permits tracing the fate of recently assimilated carbon in a mature deciduous forest, New Phytol., 172, 319-329, 2006.

Keel, S. G., Campbell, C. D., Högberg, M. N., Richter, A., Wild, B., Zhou, X., Hurry, V., Linder, S., Näsholm, T., and Högberg, P.: Allocation of carbon to fine root compounds and their residence times in a boreal forest depend on root size class and season, New Phytol., 194, 972-981, 2012.

Keeling, C. D.: The concentration and isotopic abundances of atmospheric carbon dioxide in rural areas, Geochim. Cosmochim. Ac., 13, 322-334, 1958.

Kuzyakov, Y. and Domanski, G.: Carbon input by plants into the soil. Review, J. Plant Nutr. Soil Sc., 163, 421-431, 2000.

Kuzyakov, Y. and Gavrichkova, O.: Time lag between photosynthesis and carbon dioxide efflux from soil: a review of mechanisms and controls, Glob. Change Biol., 16, 3386-3406, 2010.

Kuzyakov, Y., Kretschmar, A., and Stahr, K.: Contribution of Lolium perenne rhizodeposition to carbon turnover of pasture soil, Plant Soil, 213, 127-136, 1999.

Landhäusser, S. M. and Lieffers, V. J.: Photosynthesis and carbon allocation of six boreal tree species grown in understory and open conditions, Tree Physiol., 21, 243-250, 2001.

Leake, J., Ostle, N., Rangelcastro, J., and Johnson, D.: Carbon fluxes from plants through soil organisms determined by field ${ }^{13} \mathrm{CO}_{2}$ pulse-labelling in an upland grassland, Appl. Soil Ecol., 33, 152-175, 2006.

Meharg, A. A.: A critical review of labelling techniques used to quantify rhizosphere carbon-flow, Plant Soil, 166, 55-62, 1994.

Moustakas, N. K. and Ntzanis, H.: Dry matter accumulation and nutrient uptake in flue-cured tobacco (Nicotiana tabacum L.), Field Crop Res., 94, 1-13, 2005. 
Murage, E. and Voroney, P.: Modification of the original chloroform fumigation extraction technique to allow measurement of $\delta^{13} \mathrm{C}$ of soil microbial biomass carbon, Soil Biol. Biochem., 39, 17241729, 2007.

Pataki, D. E.: The application and interpretation of Keeling plots in terrestrial carbon cycle research, Global Biogeochem. Cy., 17, 1022, doi:10.1029/2001GB001850, 2003.

Pregitzer, K. S., Dickmann, D. I., Hendrick, R., and Nguyen, P. V: Whole-tree carbon and nitrogen partitioning in young hybrid poplars, Tree Physiol., 7, 79-93, 1990.

Pumpanen, J. S., Heinonsalo, J., Rasilo, T., Hurme, K.-R., and Ilvesniemi, H.: Carbon balance and allocation of assimilated $\mathrm{CO}_{2}$ in Scots pine, Norway spruce, and Silver birch seedlings determined with gas exchange measurements and ${ }^{14} \mathrm{C}$ pulse labelling, Trees, 23, 611-621, 2008.

R Core Team: R: A Language and Environment for Statistical Computing, R Foundation for Statistical Computing, available at: http://www.r-project.org, 2013.

Ruehr, N. K., Offermann, C. A., Gessler, A., Winkler, J. B., Ferrio, J. P., Buchmann, N., and Barnard, R. L.: Drought effects on allocation of recent carbon: from beech leaves to soil $\mathrm{CO}_{2}$ efflux, New Phytol., 184, 950-961, 2009.

Street, L. E., Subke, J. A., Sommerkorn, M., Heinemeyer, A., and Williams, M.: Turnover of recently assimilated carbon in arctic bryophytes, Oecologia, 167, 325-37, 2011.

Streit, K., Rinne, K. T., Hagedorn, F., Dawes M. A., Saurer, M., Hoch, G., Werner, R. A., Buchmann, N., and Siegwolf, R. T. W.: Tracing fresh assimilates through Larix decidua exposed to elevated $\mathrm{CO}_{2}$ and soil warming at the alpine treeline using compound-specific stable isotope analysis, New Phytol., 197, 838-849, 2012.
Thornton, B., Paterson, E., Midwood, A. J., Sim, A., and Pratt, S. M.: Contribution of current carbon assimilation in supplying root exudates of Lolium perenne measured using steady-state C labelling, Physiol. Plantarum, 120, 434-441, 2004.

Warembourg, F. R. and Estelrich, H. D.: Towards a better understanding of carbon flow in the rhizosphere: a time-dependent approach using carbon-14, Biol. Fert. Soils, 30, 528-534, 2000.

Werner, C., Schnyder, H., Cuntz, M., Keitel, C., Zeeman, M. J., Dawson, T. E., Badeck, F.-W., Brugnoli, E., Ghashghaie, J., Grams, T. E. E., Kayler, Z. E., Lakatos, M., Lee, X., Máguas, C., Ogée, J., Rascher, K. G., Siegwolf, R. T. W., Unger, S., Welker, J., Wingate, L., and Gessler, A.: Progress and challenges in using stable isotopes to trace plant carbon and water relations across scales, Biogeosciences, 9, 3083-3111, doi:10.5194/bg-9-30832012, 2012.

Werner, R. A., Bruch, B. A. and Brand, W. A.: ConFlo III - an interface for high precision $\delta^{13} \mathrm{C}$ and $\delta^{13} \mathrm{~N}$ analysis with an extended dynamic range, Rapid Commun. Mass Spec., 13, 12371241, 1999.

Werth, M. and Kuzyakov, Y.: ${ }^{13} \mathrm{C}$ fractionation at the rootmicroorganisms-soil interface: A review and outlook for partitioning studies, Soil Biol. Biochem., 42, 1372-1384, 2010.

Yevdokimov, I., Ruser, R., Buegger, F., Marx, M., and Munch, J.: Microbial immobilisation of ${ }^{13} \mathrm{C}$ rhizodeposits in rhizosphere and root-free soil under continuous ${ }^{13} \mathrm{C}$ labelling of oats, Soil Biol. Biochem., 38, 1202-1211, 2006.

Yevdokimov, I. V, Ruser, R., Buegger, F., Marx, M., and Munch, J. C.: Interaction between rhizosphere microorganisms and plant roots: ${ }^{13} \mathrm{C}$ fluxes in the rhizosphere after pulse labeling, Eurasian Soil Sci., 40, 766-774, 2007. 